\title{
Globalization And The Federal Reserve
}

\author{
Michael Cosgrove (E-mail: mcos@gsm.udallas.edu), University of Dallas
}

Daniel Marsh (E-mail: dmarsh@gsm.udallas.edu), University of Dallas

\begin{abstract}
A group of developing countries including China, India and Mexico entered the global marketplace post-1980 making a major contribution to disinflation in the U.S. and other developed countries. Movement by developing countries toward free trade led to unexpectedly large gains from specialization and exchange including the contribution to global disinflation through flows of goods, capital, technology and in particular abundant labor. These gains from trade led to a slowing in U.S. cost-push inflation pressures and enhancement of productivity gains. Gains from free trade have been widespread, with benefits accruing to both developed and developing countries in the period since 1980. In comparison, gains from trade were restricted primarily to developed economies in the 1945 to 1980 time period.
\end{abstract}

The Federal Reserve and other central banks followed monetary policies conducive to the post1980 period of disinflation but the contribution to disinflation through gains from trade does not seem to be incorporated into the monetary policy of central banks. In Japan, disinflation turned into deflation and Germany's disinflation is on the verge of doing the same. Deflation concerns are also voiced in the U.S. The premise of this paper is that the overshoot from the price stability objective to deflation fears or outright deflation on part of the Federal Reserve and other major central banks is due to gains from trade with developing countries. Policy implication -- the Federal Reserve and other central banks need to increase the quantity of money at a more rapid pace than would normally occur to account for the contribution to disinflation from gains from trade among developed and developing countries.

\section{Introduction}

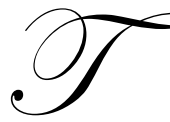

he Federal Reserve has been successful in reducing the rate of inflation over the past twenty years through use of a prudent monetary policy (Friedman, 2003). Inflation experiences during the latter 1960s and 1970s suggested that excessive issuance of money resulted in increasing price levels. The authors of this paper suggest that gains in trade due to movement toward free trade among developed and developing economies in the post-1980 era make a meaningful contribution to the disinflation process.

Chairman Alan Greenspan (2002) appears to recognize but has not acted on this - “...many forces are at play that complicated the link between money and prices. The widening globalization of market economies in recent years, for example, is integrating a growing share of previously local capacity into an operationally meaningful world total. That process has, at least for a time, brought substantial new supplies of goods and services to global markets. In addition, the more rapid of technological innovation, so evident in the United States, has boosted the pace at which our productive potential is expanding. These shifts in aggregate supply - whether foreign or domestic in origin - influence the relationship between money and prices."

Faster growth in aggregate supply, due in part to globalization, suggests it is prudent to increase the quantity of money at a faster pace than otherwise. Faster growth in aggregate supply means lower inflation rates, other things equal. Standard models of international trade generally show that free trade is welfare-improving. Welfare-improving benefits of specialization and exchange are typically thought of as flowing through channels such as improved consumer choice, better quality products and services, and more efficient allocation of physical and human capital from lower to higher value-added production. However, the positive contribution of movement toward free trade among developed and developing economies results in more rapid increases in aggregate supply 
and lower aggregate increases in price levels in developed countries and is an important channel to help achieve low rates of inflation.

\section{Framework For International Trade}

Most economists favor open economies and free trade, as the benefits of exchange of goods and services among countries are perceived to greatly offset associated costs of movement to more open economies. The crux of the argument is that individuals, companies and countries should specialize in and exchange activities in which they are relatively more efficient. The principle of trade evolved from Adam Smith's absolute advantage in 1776 to David Ricardo's comparative advantage in 1817.

Comparative advantage is the catalyst in the push toward open economies and free trade. Countries benefit when they specialize in production of goods and services in which they have a comparative advantage and exchange for goods and services from other countries that specialize and have a comparative advantage in those other goods and services. This process leads to an improvement in global income as sets of goods and services can be produced at lower costs and/or improved quality.

In particular the gain from exchange is the improvement in welfare from redistribution of an existing set of goods. In comparison the gain from specialization is the increase in total output when countries produce more efficiently.

Figure 1

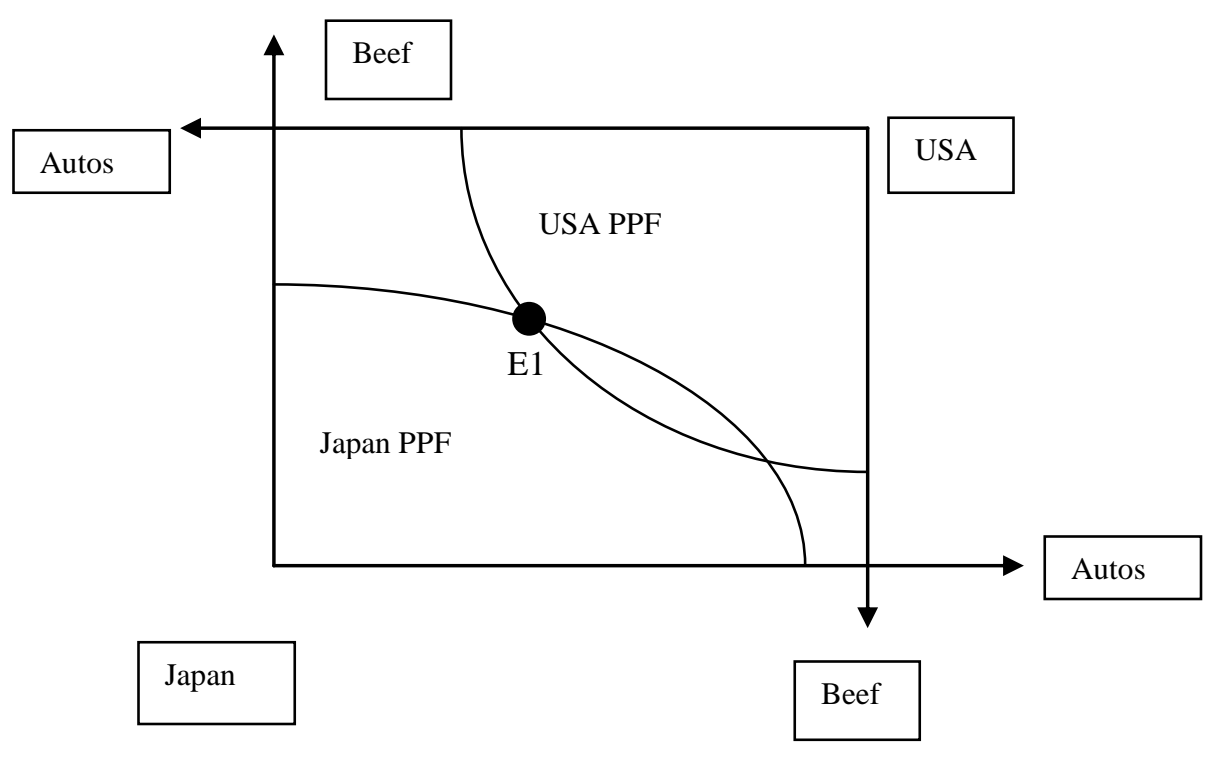

The gain from specialization is positive if, in autarky equilibrium - no trade - the marginal rate of transformation - slope of the production possibilities frontier - is different in different countries as shown in Figure 1. E1 is the production point for both countries in autarky. Width of the box is total auto output while height of box is total beef output.

Production adjusts in each country as countries move toward free trade equilibrium. Each country produces more of its comparative advantage good until the MRT is equalized across countries. This increases total output of both goods, which is gain from specialization, Figure 2. The free trade equilibrium is at E2 where Japan produces more autos and less beef while the U.S. produces more beef, less autos. The box increases in both height and width the movement out from the dashed line -- showing that total output of both goods increases. 
Figure 2

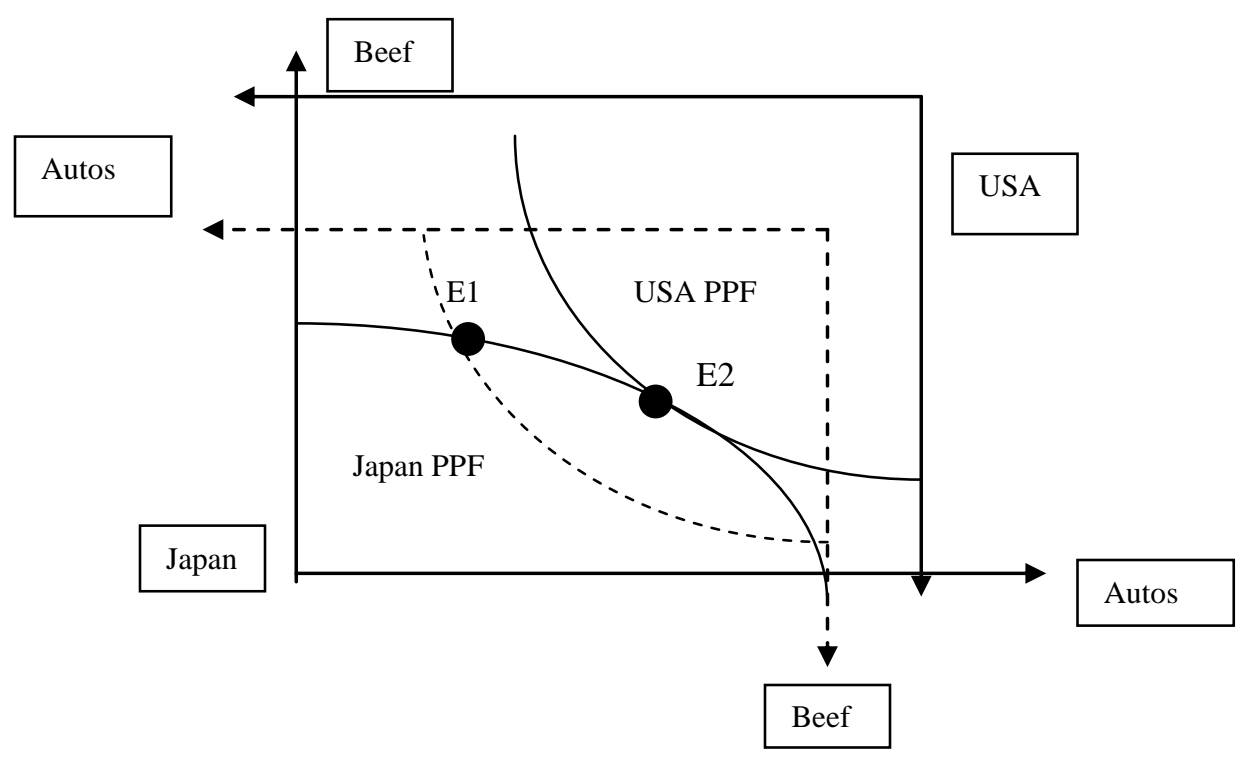

In achieving overall aggregate gains from trade, the mix of goods and services produced in various countries may change resulting in winners and losers. The degree of losers and winners varies from country to country but income redistribution can occur from the winners to the losers.

A later alternative explanation of comparative advantage is the Heckscher-Ohlin model of international trade. Their argument was that comparative advantage is due to differences in factor endowments among countries. Countries differ from each other in terms of not only productive resources but in how goods are produced using different proportions of those factors of production. A country is able to produce a product at a lower cost if its production uses a relatively larger proportion of a more abundant factor in that country. This model suggests therefore that a country will tend to export those products that make intensive use of factors that are locally abundant while importing those products that make intensive use of factors that are locally scarce. This model implies that the observed pattern of trade is determined by differences in factor endowments, as opposed to differences in productivity that underlie Ricardo's comparative advantage version. The Heckscher-Ohlin model is intuitively appealing but Wassily Leontief raised questions about the model's validity. This model, like the previous one, does not necessarily capture the dimensions of the losers from increased trade.

However both versions of comparative advantage provide strong theoretical support to open economies and free trade. A limitation of comparative advantage is that it suggests countries tend to export and import unique types of goods, and one should not expect countries to be importing and exporting the same or similar goods. However 57 percent of U.S. trade in 1996 occurred within the same four-digit industrial classification as opposed to between industrial classifications. Intra-industry numbers for Japan and Europe were 20 percent and 60 percent respectively. Japan has less intra-industry trade since its factor endowments are very different from those of the U.S. and Europe (Ruffin, 1999.)

Recent theoretical developments better explain intra-industry trade and further strengthen the case for open economies and free trade. New trade theory argues that specialization may lead to increasing returns to scale instead of the constant returns assumption used in prior trade models. A country specializing in production of a good may encounter economies of scale as production is increased, with lower unit costs and increases in productivity contributing to improvement in aggregate supply. This leads to increasing returns to specialization, not diminishing returns. 
In economic sectors in which significant output levels are required to reach meaningful scale economies, it may only require a few firms to produce the necessary output for the world economy. New trade theory suggests that in particular economic sectors, countries with first movers could have a sizeable advantage if large output levels are necessary to reach scale economies. Factor endowments assume less importance in this environment, as first mover advantages may be a deciding factor. An implication of first mover advantages is that government intervention may occur in attempting to assist companies to achieve first mover advantages in sectors expected to experience scale economies at high levels of output. Government intervention can conflict with the ideals advanced of open economies and free trade. In certain circumstances, new trade theory could lead to sizable changes in the mix of goods produced in various countries with major winners and losers.

Exchange of goods among countries can also create dynamic growth gains. Economic growth occurs due to increases in factor endowments and technological improvement. More open economies increase competitive pressures which may lead to positive impacts such as efficiency gains, increases in domestic saving, real income gains, access to capital goods and technology, technology diffusion, reduction of market power of domestic firms, faster growth in aggregate supply and access to larger markets in the global economy. Dynamic growth gains became more apparent the past twenty years as developing countries entered the globalization process.

It is generally accepted that policies limiting movement toward free trade are likely to result in actual per capita income failing to achieve potential per capita income (Irwin and Tervio, 2001). The reverse also holds that moves toward globalization generally reduce poverty. There is strong evidence that specialization and exchange of technology lead to improvement in global income. Trade policy outcomes in the aggregate are clearly positive and the textbook analysis using community indifference curves demonstrates that.

The U.S. general public is not as enamored of free trade benefits as the theoretical and empirical support for open trade suggests. Only a modest majority of Americans rated the concept of globalization positive (Kull, 2000).

It is clear that benefits of trade are not as universally accepted as the theoretical and empirical support for free trade might suggest. This is understandable as many people perceive and evaluate issues such as trade in their own self-interest and perceived interest of others. For instance, people in the U.S. whose standard of living is dependent on interest income may have found that their interest income has seen a meaningful reduction over the past few years. They may not have associated part of decrease in interest income with gains from trade, but should fears of deflation become pronounced, interest-income-dependent people may relate that to globalization and vote accordingly.

There are many dimensions of trade such as employment and income concerns, environmental concerns, social issues and cultural concerns that may not be adequately incorporated in the aggregate outcomes. The StolperSamuelson theorem illustrates for instance that when a country imports labor-intensive goods, a segment of the country's labor force - the lower skill level workers -- tend to be losers. More recent work such as that of (Scheve and Slaughter, 2001) also illustrates the role of individual preferences, as supporters of trade barriers include those with home ownership in countries with a manufacturing mix concentrated in industries facing a comparative disadvantage. Both current factor income as well as asset values influence preferences in standard trade models.

\section{International Trends}

In perspective, the first globalization period from 1870 to 1914 , incorporated the spread of the industrial revolution. The second globalization wave -- from 1945 to 1980 -- was primarily, according to the World Bank (2002), among developed rich countries. In the second wave, institutional frameworks such as the IMF and GATT evolved toward the end of WWII and the years immediately following and served primarily developed countries. Reduction of trade barriers among these rich countries was very successful, leading to the rapid expansion in exchange of manufactured goods and gains in scale economies and productivity. Developing countries had trade barriers in place during this time period that limited trade with each other and also limited trade with developed countries. 
Developing countries as a result did not participate in the growth of global manufacturing and services trade. The 1945-1980 period of globalization was among rich countries of similar heritage. The cultures are very distinct but the dimensions of the heritage of Western cultures are similar among the U.S. and Western Europe. Japan's culture, in comparison, was substantially different from that of the U.S. and Western Europe, but Japan's location, and its ability to separate the economic dimension from the religious dimension allowed Japan to fully benefit from trade in that period. This globalization time frame happened to coincide with the period of income redistribution and development of social safety nets in the three geographic areas, which allowed monetary compensation, in part, for the losers from free trade. Rodrik (1998) suggests there is evidence of a strong positive relationship between openness and size of government.

The current or third globalization wave according to the (World Bank, 2002) started around 1980 and had three major characteristics: 1) a group of developing countries that came into the global marketplace such as China, India, Mexico, Malaysia, Thailand, Hungary and the Philippines that have lower cost structures than the U.S., Western Europe and Japan, 2) major increases in capital flows including human capital among developing and developed countries and 3) a group of developing countries that fell further behind, which includes most of Africa, some Middle Eastern countries and various former Russian satellite countries. Major differences between the current and previous globalization waves are that the current wave incorporates developing countries with much lower labor costs and much smaller social safety nets. In addition this globalization wave is accompanied by very large physical and human capital flows.

This third wave of globalization coincides with the major movement toward global disinflation. The Federal Reserve under Paul Volcker and then Alan Greenspan pursued disinflationary monetary policy at the same time that developing countries opened their economies. China's economy began to open in 1980 at the hands of Senior Leader Deng Xiaoping as he began to dismantle the adverse effects of Chairman Mao's Cultural Revolution. Senior Leader Deng opened China's ports to foreign investment, encouraged growth of small enterprises and started to dismantle large state-owned entities. India's economy was regulated heavily but it slowly began to open in the 1980s. It picked up speed in1991 as Prime Minister Rao reduced tariffs and allowed private firms to compete with previously protected government monopolies.

The end of the Cold War allowed more developing countries to enter the global marketplace. Mexico and Central and South America began opening their economies in the 1980s after following primarily an import substitution trade policy. NAFTA, signed in 1993, created a free trade area in North America. Specialization and exchange allowed the benefits of free trade to flow through various channels involved in globalization -- labor, goods, capital, outsourcing, technology and information. Benefits of lower labor cost structures in developing economies are transmitted to the developed economies in the form of disinflation pressures. This third wave of globalization, in essence, created global labor and capital markets where countries having an abundant resource have a competitive advantage. Developing countries such as India, China and Mexico have an abundance of available labor and low wage rates while developed countries such as the U.S. have an abundance of capital. Both developed and developing countries enjoyed real income gains (Cosgrove, Marsh, 2003).

\section{U.S. Productivity And Real Wage Performance}

The Stolper-Samuelson theorem, as indicated, suggests for instance that when a country imports laborintensive goods, a segment of the country's labor force - lower skill level workers -- tend to be relative losers. Outsourcing of U.S. blue collar jobs occurred for decades as a byproduct of comparative advantage and gains from trade. Hourly compensation costs for production workers in 2001 varied from $\$ 2.34 / \mathrm{hr}$. in Mexico, $\$ 3.02 / \mathrm{hr}$. in Brazil, $\$ 5.70 / \mathrm{hr}$. in Taiwan to $\$ 20.32 / \mathrm{hr}$. in the U.S. Compensation costs include wage and salaries plus benefits (U.S. Department of Labor, 2002). Johnson (2003) estimates that the hourly labor rate in China is approximately $\$ 0.40$. Chen (2003) estimates the hourly wage rate of Chinese manufacturing workers is about 2 percent of the U.S. average manufacturing hourly wage rate. Developing economies have a distinct labor cost advantage compared to developed countries for both blue and white-collar occupations. 
Current technology allows developed country white-collar jobs to be outsourced to countries such as China and India as labor force skill levels allow. Developed country manufacturing as well as non-manufacturing firms both have the potential of improving their supply chain effectiveness through outsourcing of jobs. Some sources suggest that over three million U.S. white-collar jobs in areas such as IT, finance and medical will move to countries such as China, India, Russia and the Philippines (Schwartz, 2003). White-collar employment makes up approximately 60 percent of total unemployment in the U.S. Both blue and white-collar U.S. jobs can be expected to incur further outsourcing. This expectation acts as a limiting factor on U.S. wage and salary increases due to worker concerns over the cost advantage of foreign competition.

Comparison of productivity and real compensation trends in the two post-WWII globalization periods allows one to see the impact of globalization on U.S. labor compensation trends. The 1945 to 1980 time frame was characterized by trade among developed rich countries while the post-1980 stage incorporates trade among developing and developed countries. Table I data for the stage of trade among developed countries begins in 1951 not 1945.

Gains in real hourly compensation closely matched gains in labor productivity over the 1951-1980 period. This is consistent with standard neoclassical distribution theory, in which compensation of factors is strictly proportional to their marginal products. See for example Clark (1908) or Ferguson (1969).

However, during the 1980-2002 time frame, real hourly compensation of U.S. workers grows at only 57 percent of the rate at which labor productivity increases. This anomaly needs explaining when compensation of factors is supposed to be proportional to marginal productivity.

Some of this difference may be due to measurement errors in the price deflators used by the Bureau of Labor Statistics. However, our thesis is that a major cause of the decoupling of real wage gains and productivity gains in the U.S. in the 1980-2002 period is globalization. In this third wave of globalization, the U.S. experienced an unprecedented volume of trade with poor but labor-abundant countries. Workers in the U.S. are no longer competing against each other or against workers in other rich countries. They are now competing against skilled, educated workers in places such as Mexico, China and India, where real wages are substantially less.

Table 1

Labor Productivity v. Real Compensation

(Average Annual Percentage Change)

\begin{tabular}{cccccc}
\hline Time Frame & Output/hr. & $\begin{array}{c}\text { Real Comp./ } \\
\text { Hr. } *\end{array}$ & Gap & $\begin{array}{c}\text { Labor Comp. } \\
\text { Share }\end{array}$ & PCE** \\
\hline $1951-79$ & 2.21 & 2.19 & 0.02 & 0.34 & 3.8 \\
$1980-02$ & 1.94 & 1.1 & 0.84 & -0.16 & 3.2 \\
\hline$*$ Compers
\end{tabular}

* Compensation ' wages and salaries plus private benefit plans and employers' contributions for social insurance.

** PCE ' personal consumption expenditure chain-type price index.

Source: BLS

An outcome in which increases in U.S. real compensation lag U.S. productivity increases may also be suggested by the Stolper-Samuelson theorem. This theorem suggests that scarce resources for the U.S. are labor and labor compensation while capital is the abundant factor. In comparison, labor and low wage rates are the abundant factors for developing countries such as India, China and the Philippines. The slowdown in real compensation trends occurring in the U.S. is implied by the competitive globalization process. A combination of labor immigration to the U.S. as well as outsourcing of jobs from the U.S. to developing countries acts to dampen U.S. worker expectation of real compensation increases.

Most accept the idea that compensation levels offered by firms are directly related to worker productivity as higher productivity makes it more attractive for firms to increase employment and they are able to do so by increasing the wage offered to workers (Trehan, 2001). In a global economy with a global labor force via 
outsourcing and technology developments, U.S. firms no longer need to increase their compensation packages as much as before to attract workers. U.S. firms can hire people in India, China and other developing countries as opposed to in the U.S. This allows for a higher return to capital under the premise that the decision to hire workers outside the U.S. is cost-effective.

The so-called New Economy period is typically given a start date around 1995. The gap between hourly output and real hourly compensation was approximately one percent per year during this time frame. Real hourly compensation increased during this period but productivity gains increased faster than the increase in unit compensation. This suggests that returns from the productivity gains continue to flow to other factors of production such as capital, again violating the marginal productivity theory of distribution.

Table 2

Labor Productivity v. Real Compensation

(Average Annual Percentage Change)

\begin{tabular}{lccccc}
\hline Time Frame* & Output/hr. & $\begin{array}{c}\text { Real Comp./ } \\
\text { Hr.*** }\end{array}$ & Gap & $\begin{array}{c}\text { Labor Comp. } \\
\text { Share }\end{array}$ & PCE*** \\
\hline $1995-2002$ & 2.8 & 1.8 & 1.0 & 0.08 & 1.8 \\
\hline$*$ & New Economy Era & & & &
\end{tabular}

** Compensation ' wages and salaries plus private benefit plans and employers' contributions for social insurance.

*** PCE ' personal consumption expenditure chain-type price index.

Source: BLS

\section{U.S. Monetary Policy}

The U.S. has had more than a twenty-year disinflation trend from over nine percent in 1980 to between one to two percent inflation since 1997. This disinflation occurred in the Volcker-Greenspan eras. The Volcker era saw deflation slow from over nine percent to approximately four percent in 1987. Disinflation continued under Chairman Greenspan. Friedman (2003) said: "I am a great admirer of Alan Greenspan and he deserves much credit for the improvement in performance, yet this simple explanation is not tenable. It is contradicted by the simultaneous improvement in the control of inflation by many central banks at about the same, including the central banks of New Zealand, the United Kingdom, Canada, Sweden, Australia, and still others."

Graph 1 illustrates CPI behavior for an IMF classification of advanced countries - approximately 30 countries including the U.S., Western Europe and select Far East countries. Disinflation is indeed a global dimension as indicated by Friedman.

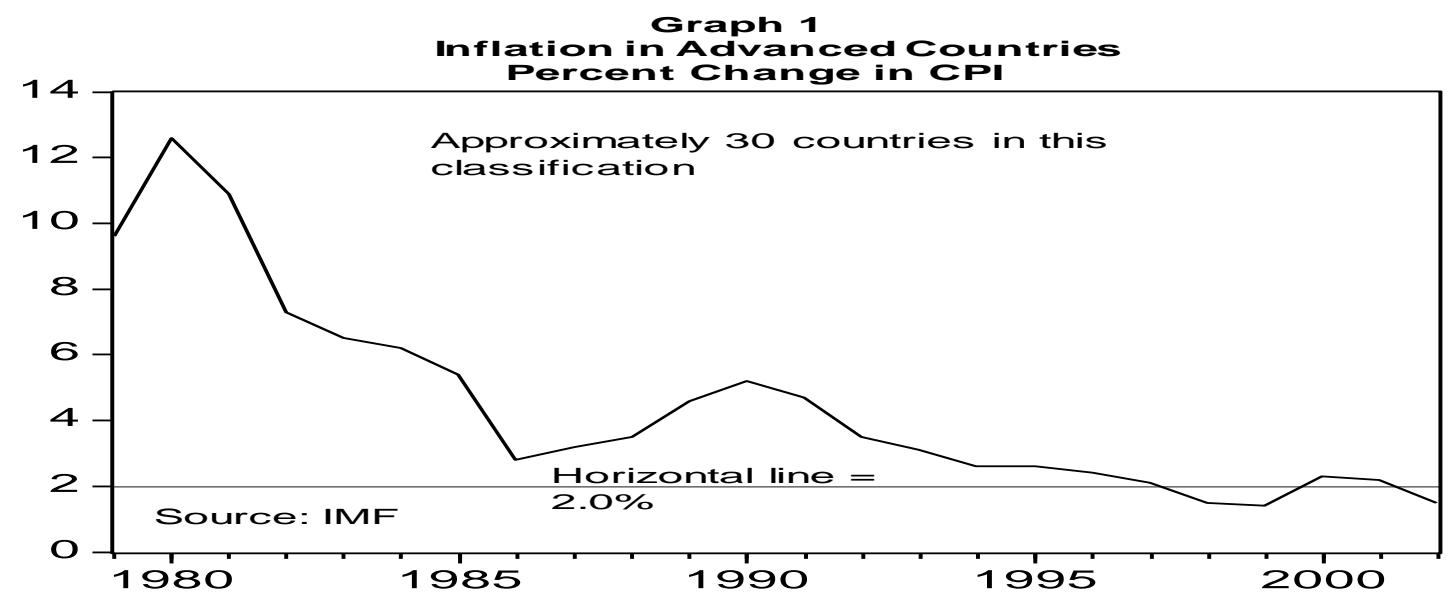


Advanced countries in all locations of the global economy achieved disinflation. This success reflects sound monetary policy, but in addition central banks around the globe have been helped by evolution of global labor markets among developing and developed countries.

In the U.S. a lower rate of increase in real compensation relative to productivity gains suggests companies incur slower rates of labor cost increases, allowing for a greater return to capital. This implies that the Federal Reserve should be less concerned about cost-push inflation. At the same time, the "good" type of disinflation pressures are occurring in the U.S. economy through rapid productivity gains in the so-called New Economy Era. The combination of productivity gains and smaller real compensation increases means that the Federal Reserve should have very few concerns about cost-push inflation as the productive capacity increases for the U.S.

Price deflation and price deflation concerns appear to have evolved from globalization trends such as global labor markets and rapid productivity gains. It does not appear that the Federal Reserve has incorporated the effect of globalization in their monetary policy decisions. Note Cosgrove (2003) for concerns about deflation. Bernanke (2003) suggests that “... I hope we can agree that a substantial fall in inflation at this stage has the potential to interfere with the ongoing U.S. recovery, and that in conceivable - though remote - circumstances, a serious deflation could do significant economic harm. Thus, avoiding a further substantial fall in inflation should be a priority of monetary policy."

"In summary, there appears to be some possibility that the recent trend toward disinflation will continue, primarily because of the potentially large amount of economic slack in the system." At the time of the Bernanke talk, the core CPI was increasing by 1.5 percent in the year ending June 2003 while the core personal consumption expenditure price (PCE) index ending in May 2003 was increasing by 1.2 percent. Bernanke (2003) said the core PCE price index "might fall from 1.2 percent currently to 0.7 percent or so by the end of 2004 . "

The following, graph 2, shows growth in the sweep-adjusted monetary base minus growth in productivity. In a quantity theory context, where $\mathrm{MV}=\mathrm{PY}$, the graph is representing $\Delta \mathrm{M}=\Delta \mathrm{Y}$, or in other words, the degree of net inflationary pressure the central bank is exerting on the economy. The average difference over the past twenty plus years is approximately 6 percent. The Federal Reserve has not met that average since 2000. The average difference between the monetary base growth and productivity is 3.8 percent from 2000:1 to 2003:2 compared to an average 6.3 percent growth from 1980:1 to 1999:4. The Federal Reserve has been stingy with money growth relative to productivity growth in the post-2000 period relative to the prior period.

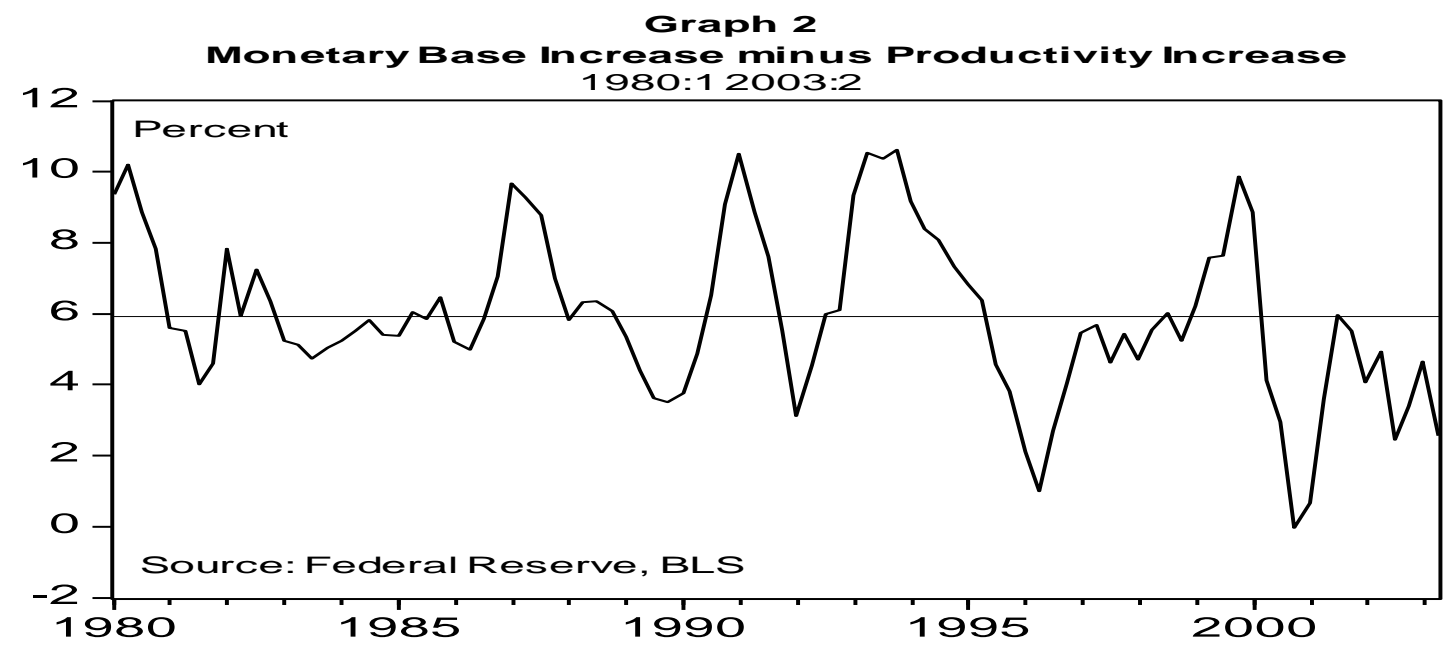


The assumption of stable velocity is dropped in graph 3. Monetary base velocity declines, reflecting in part globalization as more and more currency is held outside the U.S.

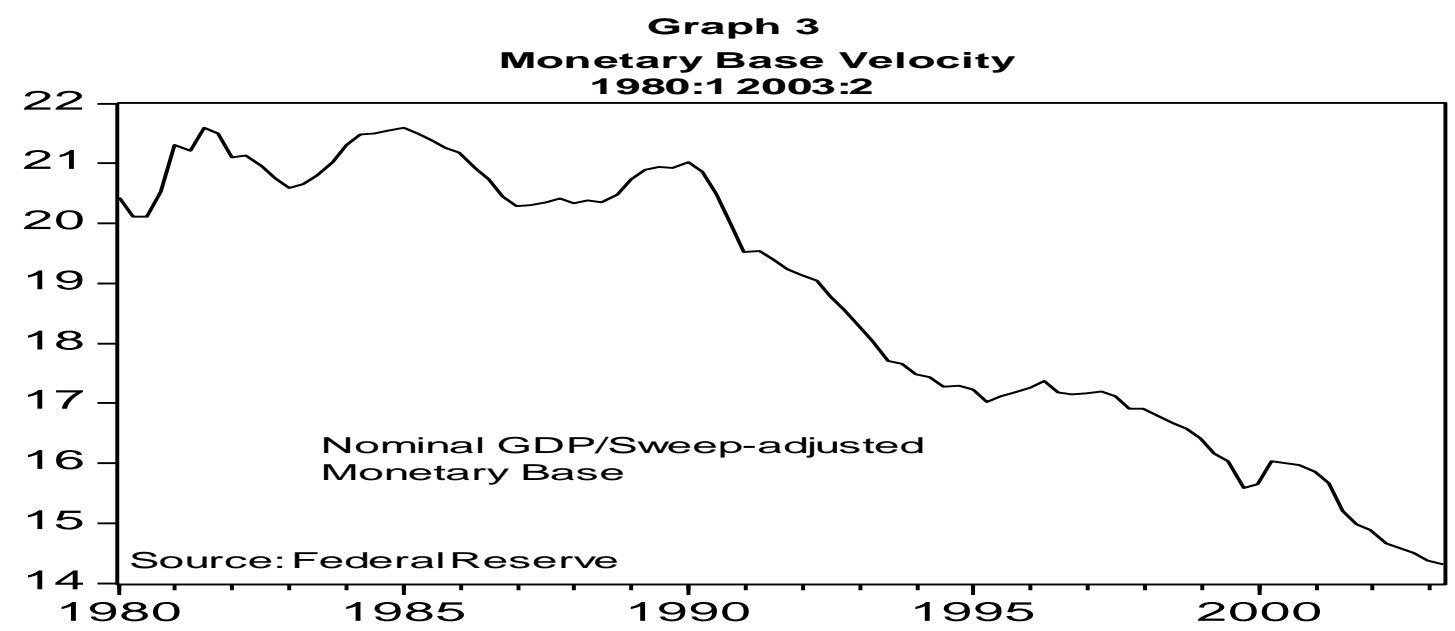

An increase in $\mathrm{Y}$ or in productivity and/or a slowing velocity - assuming no change in growth of the sweep-adjusted monetary base - implies downward pressure on the price level. In combination with fewer upward pressures on cost levels due to globalization, it becomes more apparent why disinflation has been achieved in the U.S. Also slower upward pressures on cost levels in advanced countries across the globe help explain why deflation is occurring in some countries and why it is a concern in the U.S.

Trends since the first quarter of 2000 in the sweep-adjusted monetary base, velocity, productivity and price level suggest fears of deflation shouldn't be dismissed in the U.S. It is unclear that Federal Reserve officials are incorporating the impacts of globalization on accelerating the disinflation process. Federal Reserve officials, in discussing the threat of deflation, appear confident that they can avoid deflation. The President of the Federal Reserve Bank of Richmond said: "We have been thinking about it, "deflation," and I am quite confident that we could deal with a deflationary threat successfully" (Broaddus, Jr., 2003). That degree of confidence might be warranted if it were clear that the Federal Reserve has incorporated the disinflationary impact of globalization.

\section{Summary}

The Third Wave of globalization - post-1980 - generated unexpectedly large gains from specialization and exchange leading to increases in real income for developing and developed countries that moved toward free trade. Real income gains in the Second Wave of globalization, in comparison, were primarily shared among the developed countries. Gains in real hourly compensation during the Second Wave were approximately equal to gains in productivity as compensation of factors is proportional to their marginal products.

However in the 1980-2002 period, real hourly compensation only grew at 57 percent of the rate at which labor productivity increased as standard neoclassical distribution theory failed to hold. This decoupling is contributed to by international trade as the U.S. experienced an unprecedented volume of trade with poor but laborabundant countries. U.S. workers compete against skilled, educated workers in countries such as India, China and Mexico where real wages are substantially less.

Global labor and capital markets effectively slow U.S. cost-push inflation pressures and improve productivity. That combination made a major contribution to the post-1980 disinflation experienced by the U.S. and other developed countries. Policy implication - to avoid fears of or actual deflation, the Federal Reserve as well as 
other central banks needs to increase the quantity of money at a more rapid pace than would normally occur to account for the contribution to disinflation from gains from trade among developed and developing countries.

\section{References}

1. Bernanke, Ben S. (2003). “An Unwelcome Fall in Inflation?” The Federal Reserve Board, July 23, 2003.

2. Broaddus, Alfred J., Jr. (2003). "Monetary Policy in a Low Inflation Environment." Economic Quarterly, Volume 89, (2), 1-6.

3. Chen, YiMin. (2003). "China's Still-Strong Foreign Trade." Global Insight. June. http://www.globalinsight.com/Perspective/PerspectiveDetail287.htm

4. $\quad$ Clark, John Bates. (1908). The Distribution of Wealth. New York: Macmillan.

5. $\quad$ Cosgrove, Michael. (2003). “The Fed's Complacency.” The Wall Street Journal, May 21, 2003.

6. Cosgrove, Michael and Marsh, Daniel. (2003). "Globalization and Suicide Bombers". American Society of Business and Behavioral Sciences, Las Vegas, NV, February 22.

7. Ferguson, Clarence E. (1969). The Neoclassical Theory of Production and Distribution. New York: Cambridge University Press.

8. Friedman, Milton. (2003). "The Fed's Thermostat.” The Wall Street Journal, August 19, 2003.

9. Greenspan, Alan. (2002). "Issues for Monetary Policy." The Federal Reserve Board, December 19, 2002.

10. Irwin, Douglas and Tervio, Marko. (2002). "Does Trade Raise Income? Evidence from the Twentieth Century." Journal of International Economics, Volume 58, (1), 1-28.

11. Johnson, Grant. (2003). China: The Wait and See Approach. Reed Electronics Group, June.

12. Kull, Steven. (2000). "Americans on Globalization: A Study of US Public Attitudes." Program on International Policy Attitudes, University of Maryland, 1-96.

13. Rodrik, D. (1998). "Why Do More Open Economies Have Bigger Governments?" Journal of Political Economy, Volume 106, 997-1032.

14. Ruffin, Roy J. (1999). "The Nature and Significance of Intra-industry Trade." Economic and Financial Review, Federal Reserve Bank of Dallas, Fourth Quarter, 2-9.

15. Scheve, Kenneth and Slaughter, Matthew. "What Determines Individual Trade-Policy Preferences?" Journal of International Economics, Vol. 54, (2), 2001, 267-92.

16. Schwartz, Nelson D. (2003). "Down and out in White-Collar America." Fortune, June 23.

17. Trehan, Bharat. (2001). "Unemployment and Productivity". Economic Letter, Federal Reserve Bank of San Francisco, October 12, 2001.

18. U.S. Department of Labor. (2002). "International Comparisons of Hourly Compensation Costs for Production Workers in Manufacturing, 2001.” Bureau of Labor Statistics, September 27.

19. World Bank. (2002). Globalization, Growth, and Poverty: Building an Inclusive World Economy. Chapter $1,23-51$. 